and if so also many more, are connoted by the name "Cæsar," when it refers to him ?*

So also, I think, few persons will deny that if I say, e.g., "the principal speaker was Mr. Gladstone," I am giving you, not less but more information about the speaker in question, than if, instead of "Mr. Gladstone," I say either "a member of Parliament," or "an eminent man," or "a statesman," or "a Liberal leader." It will be admitted that the predicate "Mr. Gladstone," tells us all that is told us by all these other connotative predicates put together, and more : and, if so, I cannot see how it can be denied that it also commotes more.

\title{
THE RATIONALITY OF HEDONISM.
}

By Miss E. E. Constance Jones.

What I desire to defend in this paper is the ethical doctrine that the proper end of Human Action is the promotion of Happiness, that " the conduct which, under any given circumstances is objectively right, is that which will produce the greatest amonnt of happiness on the whole" (Methods of Ethics, Book IV, Chapter I). It is a doctrine of what ought to be done, not of what merely has been or is or will be in human action; it implies a standard with which the actual has to be compared, and by which it must be judged. No doubt what ought to be is limited by what is possible; no doubt also what ought to be in some sense is; but of everything of which we can speak we may say that in some sense it is, and equally we may say, perhaps, that in some sense it is not-all depends upon the particular kind of existence which is meant. But if by is we mean existent as human conduct, then I do not see how is can be resolved into ought, though it may be coincident with it-in logical phrase, connotation mnst remain different though denotation may be identical. Of course, as far as men act rightly, denotation of is anc? ought is actually coincident.

Perhaps, in a sense, everything is good, everything is true, every-

* As the same writer elsewhere say" ("On the Importance of a True Theory of Identity," in Mind, rol. xiii, p. 358) : "In order to give this judgment its fuli meaning we nust not try to cut it down ... . reducing Cæasar to mean merely a creature that crossed the Rubicon. . . . Precisely the point of the judgnent is that the same man uniled in himself . . . say the relations of being the conqueror of Gaul, and of marching into Italy." "Casar" thus means these and othcr "differences in identity"; and it can do this only by what I call connoting them. 
thing is beautiful-and perhaps again, in a sense, Goodness is Beanty, and Beanty is Truth; but before these identifications can be received as useful, or even as significant, we need to know in what sense-a mere vagae feeling of some relation (that is, of some unity) between them is perhaps inevitable, but is merely a datum of unreflective common sense, and a starting-point, and not by any means a goal, of philosophical thought. To determine clearly and intelligibly in what sense the Good is the True, or what is the relation between Ought and Is, is a task at which Philosophy must aim, but which it has not perhaps yet satisfactorily accomplished. And it is the task of Philosophy or Metaphysics, and is no more the business of the Science of Ethics than a determination of the relation between Mind and Matter is the business of the Science of Psychology. No doubt Ethics, considered as a Science, has what has been called a metaphysical basis, and the determination of this is of the last interest and importance; bat it is not the science itself, and the great question of scientific Ethics-what is it that is Right?-bas to be discussed separately from the investigation of that basis. This is simply the general scientific procedure which the limitation of our powers, the "narrowness of cunsciousness," makes necessary in all cases. Every part is certainly part of the whole to which it belongs; bat if knowledge of any part is to be improved and increased, attention must for the time be concentrated on it. The very breath of life to us, as thinking creatures with finite powers of attention, is abstraction and elimination.

If we, imperfect as we are, are here and now seeking the guidance of Ethical Science, are asking after the End which we ought to aim at, we must-it seems to me-remember that the relevant End in this inquiry must be an End (1) which can be attained, or approximated to, by human action, and (2) which is desirable to us, being what we are, and limited as we are.

It certainly cannot be an all-embracing Find, which ignores or attempts to obliterate the distinction between Good and Bad, or which identifies what is Good with what is. From some points of view perhaps everything may be "very good," or at least may be the best that is possible; from the point of view of the Absolute everything-that is, every part of itself-may have worth; from a point of view which I suppose may be called evolutional, what is, and is conjectured to be coming to be may be held to be Good, quh existent and expected. Bat we are (or at any rate appear to ourselves to be) mere parts of the world, and in part at least the result of something not ourselves; and we find that while some things and tendencies in the world, and some results of human action, seem to us desirable, others are not so. 
It is sometimes said that the End which is desirable for man must be deternined by a consideration of his nature-for instance, we find this view in the great Greek philosophers and in our own Bishop Butler. But it cannot be supposed that a mere observation of what man is can give us guidance as to what man ought to do; if it could, we should need no guidance.

To get guidance for right action from obserration of the natare of man we must take with us to that observation a principle of selection-Plato and Aristotle take Conformity to the Reason that is part of man's natare, and Butler very decidedly, though not so conspicuousls, does the same; for all of them, the "Nature" that we ought to follow, is just that part of man's nature which they regard as leading to right action; and as long as we get no further than this, ethical thought is of course essentially circular i $C f$. Wethods of Ethics, 5th Edition, p. $377, \&$ c.). What is reasonable is to follow Nature, but if we go to Nature as it (in the whole and actually) is, we find that the reasuncable part of Nature is the only part that we ought to be guided by.

No competent moral thinker, I suppose-at least none to whom I should attempt to refer-would refuse to admit that what is reasonable in buman action is right, that the right end for man is the End approved by Reason.

In the controversy as to Ends which rans through the ethical systems of ancient and modern thought, we find frst, and chiefly, a conflict between Pleasure and Virtue as competitors for the rank of the Ultimate Good, or the End of Action. That is to say, Good (or Right) conduct bas been held to consist in either (1) promotion of Pleasure or (2) practice of Virtue, conceived as something other than promotion of Pleasure. Clearly, as long as we merely say that Good or Right Conduct consists in Virtue, or that Virtue is the End of Action, we have not advanced a single step towards a guide of Action or a Science of Conduct; we have seen that to refer to "Nature" is equally vague ; and Perfection, Self-realisation or Self-development, as Ends, share the same defect. Recourse to crude Intritionism, whether Perceptional or Dogmatic, is not common among ethical thinkers in the present day, and perhaps hardly needs serious attention; but I shall return to it for a moment, at a later point, in connection with a brief consideration of "Selfrealisation," which is put forward as the End by the school of Ethical writers who are the most prominent opponents in this generation of Utilitarianism or Rational Hedonism.

I should admit the contention that we must appeal to Reason to gride us to the End or Chief Good for man, and also that Reason requires that in this search we should pay careful attention to man's 
actual nature : we must undonbted]y know what moll are like, what their constitution and cireumstances in this world are, what is possible for them, before we can even consider the question of what is reasonable for them to do.

It seems almost superfuous bere to call to mind that man is a creature both spiritual and materia!, both intellectual and sensitive -it is by such abstractions and distinctions that we try to set before ourselves, in words and definite thoughts, that complex human nature which is so familiar to us all, in ourselves and in others. That man is sensitive (= capable of feeling Pleasure and Pain) and rational, conscious and self-conscions, intellectual, active and volitienal, none would deny.

The Good for such a being, the End which to him is worth pursuing, must be some Good of consciousiess. Therefore the question becomes: What good of conscionsness is it rational for a sensitive, intelligent, and active being to pussue? Is it a good of Will or of Feeling or of Intellect, or some combination of these? We cannot, of course, hape any of these constituents in actual isolation, but it may be that in every case it is some one element which we perceive to bave intrinsic value- to be Good in itself.

That such intrinsic worth can be asserted of Knowledge or of mere intellectual power is not (so far as I know) maintained by anyone-if it were, Kant has, I think, sufficieutly refuted it ( $C f$. Grundlegung zur Metaphysik der Sitten, beginning of Section I). Can we say then, with Kant, that "the only good thing in the world or even out of it, is the Good Will "- that is, the will to do that which is esteemed to be right, and to do it because esteemed right?

To hold this view is to maintain that no "well-intentioned" person can do wrong, that there is no snch thing as conscientious blundering, that what is done does not matter, but only the motive from which it is done. This seems ntterly contrary both to Coumon Sense and Reflection, and it is in a certain important sense, selfcontradictory-for the Good Will is held to be of supreme importance not in one man only but in all, and the influence of many well-meant actions, which in ordinary life are what would be called ill-judged, may be to cause others to act from very reprehensible motives-resentment, irritation, jealous, and so forth. So that manifestations of the "Good Will" in one may hinder that Will in others.

The view that no one ever desires what does not seem to him good and right is an exaggeration of Kant's doctrine into the doctrine that subjectire wrong-doing is an impossibility-and the view that the object of desire is always good (= desirable, what onght to be desired), 'is a further extension of the doctrine of the 
impossibility of wrong-doing-to the effect that all oljective wrongdoing is impossible (on the view that action is prompted by desire).

All these doctrines seem to me to be outrageous paradoxesutterly at variance with the facts of experience and with sound judgment, and they would seem to make any Science of Ethics, auy systematisation of right conduci, impossible or unnecessary-to a great extent they are attempts to break down the distinction between what ought to be and what is.

I will ask next what can be said for the view that excellence of Feeling-that is, Pleasure and absence of Pain-is that which is, for man, intrinsically worth having; 'and will afterwards consider some objections to the doctrine that it is so, and the competing view that the Good for man must be Self-realisation-a good corresponding to all the elements of his nature.

The question here is whether Happiness (= Pleasure and absence of Pain) can reasonably be regarded as intrinsically and ultimately worth aiming at-whether it is something which is in itself to be desired, something which makes the portion of consciousness in which it occurs intrinsically worth living through; and whether, on the other hand, its aosence is something whicl makes the portion of consciousness in which it occurs in itself worthy of avoidance. We might, similarly, abstract in considering Truth or Beauty without reference to the processes by which the one had been discovered or the other produced-though of course in eitber case there can be no actual separation corresponding to the abstraction or distinction.

I shouid like, in the first place, to distinguish between Pleasure (and Pain) and causes or concomitants of Pleasure (or Pain), and to emphasise the point that I am trying to abstract from differences of cause and accompaniment, and to fix attention upon the actual characteristic of consciousness which we anderstand by Happiness or Pleasure or Pleasant Feeling, and its reverse-in other words, to consider exclusively what has been called the Feeling-tone of consciousness, i.e., its pleasurableness or painfulness. The psychological question as to what men can and do desire I am not at this noment inquiring into; but I should like here just to draw attention to the fact (1) that Psychological Eedonism (the doctrive that no one does or cun desire anything but his own Pleasure or freedom from Pain) has been, as I think, conclusively disproved, (2) that even if it were true, it would not only not be a necessary presupposition of Ethical Hedonism (whether Egoistic or Universalistic) but absolutely incompatible with that doctrine.

As Plato thought it would be easier to exhibit the relations of the Virtues in the individual human soul if he looked at them as 
"writ large" in the State; and, as in e.g., psychological study, knowledge may be very much helped by observation of some abnormally exaggerated manifestation: so perhaps the worth and unworth of Pleasure and Pain may be most easily seen by taking very marked cases. Take, e.g., any instance of intense pain: are we not forced to judge that such a condition, whatever its accompaniments may be, is in itself undesirable? If it were in itself desirable, then the longer it continued, and the more it were intensified, the more desirable it would be; but the reverse is the case-the more it is increased in extent and degree the more undesirable it is. And if we could imagine a whole community of sentient individuals, passing an existence of severe continucus unmitigated pain, we must surely judge that for them existence is entirely nudesirable. This, of course, is quite compatible with holding it reasonable to encounter and endure Pain for the sake of something bejond-courage and self-control are as necessary on the Utilitarian view as on any other. On the other hand, if there were a community composed of human beings who throughout their existence enjoyed absolute exemption from Pain, and a large share of positive Happiness, we must surely judge that tbeir existence would be in itself desirable; and the happier it were made, and the longer it lasted, the more desirable it would be. No doubt, in creatures such as we are, general happiness in a community would be incompatible with the prevalence of what is commovly regarded as evildoing, and perhaps incompatible with a certain degree of ignorance and strpidity-for creatures like men, the exercise of Reason and the practice of Goodness seem necessary even for the agent's own Happiness. In taking Happiness (i.e., concrete life which is happy) as Find, we have to take account of the conditions and concomitants of human Happiness. Accordingly it is sometimes said hy writers who object to Hedonistic Ethics that, though Happiness is desirable, it is not the only thing intrinsically desirable, and that Reason and the Good Will are indispensable. In reply to this, I am not only willing but anxions to admit that for any satisfactory system of Fthics, and for any human life that is worth living, Reason and a Good Will are necessary-and in Rutional Hedonism or Utilitarianism they have their due place assigned to them. For the Utilitarian makes a first and paramount appeal to Reason-he goes to Reason with the inquiry: What is it that it is right to do? What is the content of right action? What is the characteristic by which right action may be recognised ?-He acknowledges Renson as sovereign, and it is because, in his riew, Reason declares that Happiness is intrinsically worth having, and conduciveness to Happiness, the test of right action-it is because of this, that he adopts the so-called 
"Hedonistic" End. And if Reason te!ls us that it is Happinessexcellence of Feeling-that makes any portion of conscionsness intrinsically desirable, then the Volition that promotes Happiness is good; and since we cannot bave good conduct without a gond will (for conduct involves Volition) it appears that the promotion of the Hedonistic End inrolves both the supremacy of Reason and the conscious direction of the Will to rigbt. We have thus, it would seem, not a mere one-sided Good, but a Good which takes into account, and gives due place to, all the elements of man's complex nature. If it is said : This doctrine is not Hedonism, I reply that whatever it may be called, it is the doctrine which tabes as the End Happiness $=$ happy Consciousness or happy Life-unclerstanding happy to mean pleasant and free from Pain.

The controversy between the Rational Hedonist and the so-called "Idealist," or "Eudaemonist" moralist is not a controversy between "Feeling" and "Reason," or "Feeling" and "Will"-such a controversy is not possible or even conceivable, for in any controversy Reason must be advocate, judge and jury-but it is a controversy concerning the deliverances of Reason itself, in which the disputants are not agreed as to the answer that Reason gives to the question: What is Right Conduct, what is the Ultimate Good for man?

In considering how far Reason makes good the claims of Happiness to be the ultimate End, we way refer to:-

(1) Its positive claims to acceptance;

(2) The answers that can be made to ohjections;

(3) The other Ends that have been pul forward.

(I) Cnder the first head, besides what has been already urged, it may be pointed out that, on the one hand, the effort of Intuitionism to escape from the conflict and incompleteness of the precepts of Common Sense ("Dogmatic Intuitionism") has resulted in the acceptance (by the so-called "Philosophic Intuitionists," e.g., Clarke) of a principle of universal rational Benevolence, which, on the other hand, furnishes the now accepted basis of Utilitarianisma principle the truth of which seems to some extremely carefal and acute thinkers, to be intuitively perceived-to be self-evident.

It is, furtber, worthy of mention that people and conduct that we call "Good" are perhaps always felicitic (promotive of Huppiness), that disputed and difficalt cases of action are perpetually being decided by an appeal to the halance of Happiness. and that it seems inxpossible to work ont a system of Politics on any other basis than that of Utilitarianism. Also it appears that the Utilitarian principle is in fact ordinarily accepted in Politics-any governmental measure that canses more misery than happiness would, I 
think, be generally beld to be, on that account alone, sufficiently condemned. And though this argument is not in itself conclusive, still the current opinion of thoughtful and conscientious men on this head, is at least entitled to carefal consideration. And any system of Ethics I think stands self-condemned if it is out of touch and out of harmony with Politics. Another important point is, that if we look at the development of Ethical thought and Ethical standards, from country to country, and age to age, and the variation of different contemporaneous codes (Law of Honour, \&c.), the Utilitarian standard seems to unify and explain, with striking completeness and ease, the erolution that has taken place, and the divergence that exists. Further, we find that the ever-renewed Ethical controversy between Pleasure and Virtue, as the aim of Life, is explained and allowed for by Utilitarianism (Rational Hedonism). For when we examine what we mean by virtue, we find that (as Butler says): "It is that which all ages and all conntries bave made profession of in public, it is that which every man you meet puts on the show of, it is that which the primary and fundamental laws of all civil constitutions over the face of the whole earth make it their business and endeavour to enforce the practice of upon mapkind: namely, justice, veracity, and regard to cummon good" (Dissertation of the Nature. of Virtue)-that is, Justice, Veracity, and (as comparison of passages in the Dissertalion on Virtue shows) Benevolence. And it would be easy to prove that Justice and Veracity in the members of a community are fundamentally important for the general Happiness. In short, it appears that the ever-recurring moral cuntroversy between Pleasure and Virtue, is neither more nor less than a controversy between the Agent's Happiness and the Happiness of Others-and is a controversy not between Reason and Unreason, but between competing reasonable Ends; and this inevitable dualism or two-fold aspect of the End commended by Reason, still subsists witbin Utilitarianism (as in Butler's "Intaitionism" and certain modern interpretations of Self-realisation), and in the opinion of its adherents, constitates the most important difficulty of the system of Uuiversalistic Hedonism.*

It is at this node that theoreical difficulty and practical struggle chiefly centre-for it is just here (and in the question as to Free Choice) that, more than anywhere else in Etbics, the fundamental and omnipresent problem of the One in Many and the Many in One makes itself prominent. It is to be remembered that it is a difficulty in no way peculiar to Universalistic Hedonism.

* On the other hand, the explicit recognition of the dualism is one of the distinctive merits of Utilitarianism. 
(2) As regards the answers that can be made to the objections which have been brought forward against Hedonism, I can here only offer a very brief summary of the objections that seem most worthy of consideration and the answers that it seems possible to make to them.

Objection 1. - Ethical Hedonism rests upon Psychological Hedonism, and since Psychological Hedonism is to be rejected, therefore Ethical Hedonism is to be rejected.

Answer.-Ethical Hedonism is incompatible with Psychological Hedonism; for if we are, by the constitution of our nature unable to seek anything but our own Pleasure and absence of Pain, our own Pleasare cannot be what we ought voluntarily to seek, and others' Pleasure it is impossible for us to seek.

Objection 2. - The adoption of Pleasure as Find is based on a confusion between Pleusure and causes of Pleasure.

Answer-This confusion is guarded againsi by Utilitarian Moralists, who are careful to explain that it is (concrete) agreeable feeling hovever caused and accompanied that is the Hedonistic End.

Objection 3.-The Hedonistic End is impossible because Pleasare is an abstraction.

Answer-By parity of reasoning, any end is impossible; for Satisfaction, Blessedness, Activity, Virtue, Perfection, Selfrealisation, Beauty, Truth, \&c., are all abstract in the same way. In order to speak of Pleasure as End of Action no more abstraction is necessary than is required to make thought and the use of language possible to us. And it is of course not abstract pleasure (whatever tbat may be) that is the end of the Utilitarian Moralist, but Concrete Consciousness in which the feeling-element is happy or pieasurable.

Objection 4.-Pleasure is an impossible end hecause it is not intrinsically valuable, but only a serse of value.

Answer.-'Whis reminds one of Lotze's conjecture that Pleasure is our response to, our recognition of, goodness in things. But to us as conscious and sensitive creatures, nothing can be good or valuable except as it affects consciousness-the value must consist in some effect produced in consciousness. What effect in consciousness can we point out, that is distinct from concrete Pleasure or Happiness, but of which Pleasure is the sense, and the neasure? It seems sometimes to be suggested 
that the valuable effect of which Pleasure is the sense, is Self-realisation, i.e., Satisfaction of the desires of the true or rational self. But thus the pursuit of value brings us back to the point from which we started. For we mag ask: If that which is intrinsically valuable is the satisfuction of desire, is it because the object of Desire is intrinsically good or is it because Satisfaction qua Satisfaction is good (or reasonably to be chosen)? If the latter, bow does subjective satisfaction differ from Pleasure? If the furmer, either all desires are for Good -which seems inadmissible-or there is some criterion of Good by which desires may be tested, and we ask what it is? And it seems to me relevant to notice here that not only does Happiness (Pleasure and absence of Pain) appear to be the only thing which is ultimately and intrinsically desirable, from the individual point of view, to any conscious and sentient creature : but also it would seem impossible to esteem, or to be for its own sake interested in, any conscious creature deslitute of all capacity of Pleasure and Pain. A conscious but insensitive creature would be a kind of monster:* ${ }^{*}$ regard as most depraved the nature which derives Pleasure from others' pain, and very largely judge of men as Good or Bad by the things they take pleasure in, with direct and special reference to sympatby, and (I think) an ultimate reference in all cases to the felicific influence generally of the causes and accompaniments of their own Pleasare and Pain. Could we, or do we, judge anything to be Good or Bad, if incapable of feeling or producing Pleasure or Pain?

Objection 5.-Again, it has been said that Pleasure is an irrational End, because a Hedonist must evalnate pleasures of the merely sensitive nature, and compare mere sensitive values with rational values-" What is pleasant to sense need not be pleasant to thought "-what is valuable to us as sensitive beings need not be valuable to us as rational beings ( $C f$. Mackenzie, Social Plilosophy, p. 224).

Answer.-As merely sensitive we could not have any sense of value, and could not estimate Pleasure from any source, or choose any end whatever. Reason as well as Sense must act, in order that auything may be known and distinguished as "pleasant to sense." It is only as rational that a man can formulate and adopt the Hedonistic end.

* Is not finite consciousness (as far as we can see or conceire) bound up with crtpacity of Pleasure and Pain? 
Objection 1.-Pleasure is an unlesired end.

Answer.--In reply to this it seems sufficient to refer to the estimation of Happiness expressed by poets, moralists, and preachers, or in current phrases of congratulation and good wishes, or to the many witnesses, in our own consciousness and in the words and actions of otbers, that Happiness is an End actually and wirlely desired. I cannot think that it would be seriously disputed that Happiness is an end very widely desired by men, both for themselves and for others. Unless it is so desired, we must deny the prevalence both of Self-love and of Benevolence, and must be prepared to explain as the result of complicated delusion or hypocrisy, all the wishes for Happiness of which the air is full, e.g., at birthdays and weddings, and when the New Year comes round.

Objection 7.-Pleasure is indeed part of the End, and a sine qui non, but it is not the sole Find, for every part of the world and of man's nature has intrinsic worth.

Ansiver.-Though this objection seems hard to meet because it brings up the difficult question of the relation between different aspects, yet I do not admit it, hecause I think that in that which constitutes its difficulty is also to be fonnd the key to its solution.

For, lonking at the constituents of the world as we know or divine it, and regarding them as apparently parts of an actually existing whole, we are attempting to take an universal point of view, and are certainly not able to pronounce that any of those parts are intrinsically wortbless.

But when from the restricted point of view of finite and sensitive (though also rational) creatures, we endeavour to determine what ultimately desirable end can be obtained or promoted by human action, there does not seem any necessary reason why all possible ends of action (for it is with these we are concerned) should be regarded as ultimately and intrinsically desirable. And we may ask, How is the intrinsic worth, which is not Pleasure or Happiness, to be described, and in what does it consist? The difficulty here, I think, is caused by mixing up different points of view, and is evaded, as far as Ethics only is concerned, by separating them again.

In Rational Hedonism, as already pointed out, neither Reason nor the Good Will are ignored. Reason is expressly appealed to, to declare and, if you will, to constitate the End.

Objection 8.-To get Pleasure we must forget it.

Answer.-This does not seem to be anj objection really, to taking 
Pleasure as the ultimate end, hat only to making it the invariable proximate end; and Rational Hedonism by no means requires us to do this.

Objection 9.-Even supposing that Pleasare were the End, amount or sum of Pleasures is not the End, for Pleasures differ qualitatirely, and therefore are not commensurable, and cannot be added.

Answer.-I believe the real source and unfailing prop of this objection to be the difficulty of clearly distinguishing between Pleasure and the Causes and accontpaniments of Pleasure. The Causes of Pleasure are many and varied, but it is only in so far as their effect-concrete Pleasure-has common quality, that the name "Pleasure" can be applied. We cannot indeed in experience separate Pleasure from its antecedents and accompaniments, but we can distinguish it from other adjacent mental elements, as is perhaps sufficiently proved by our giving it a name. It would be as reasonable to say that because Death may result from very various conditions, therefore Death quaे Death has different quality in different cases, as to sny that Pleesure quâ Pleasure, may differ in quality according to its cause. And of conrse it is only quit Pleasure, that similarity of quality is asserted. If appeal to fact is allowed, it seens clear that men often do compare pleasures and pains in respect of intensity and duration. The medical use of palliatives and of sharp remedies, for instance, involves such comparison, and all cases in which uncongenial toil or painful privation is voluntarily undertaken for the sake of a prospective reward. We may perhaps instance here the industrial organisation of Society. The Penal Code, again, suggests a comparison of Pains (at least).

There also seems no room to doubt that in the ordinary forecasting of the fature, and deliberation as to alternative courses of action with which men are largely occupied, a weighing of Pleasures and Pains has an important place. We often try to compensate for Pain, or to comfort a person who is in distress, by something which will give pleasure. The Hedonistic calculation is carried out, not indeed with mathematical precision, but, I think, with as much approach to accuracy as, e.g., judgments that one life or action is better. than another, or that one scene or one face is more beautiful than another. Are not two happy weeks more worthy to be chosen than one, are not "forty stripes" more to be avoided than twenty? 
The difficalties presented by Hedonistic calculations in the case of a single iridividual, are no doubt increased when the calculus is made universalistic-embracing a consideration of the happiness of Self and of Others. But whatever the difficulties may be, we all go on trying to make the calculation. And though there are difficulties, it is no more than the trath to say that we all do know a good deal about the Canses of Happiness to ourselves and others-just as, e.g., we know a guod deal about the nutritive, \&c., properties of food, although we admit that "one man's meat is another man's poison," that infants require different food from adults, and invalids need other fare than those in robust health; e.g., the laws of any civilised country and the rales of positive morality embody a great deal of knowledge on this subject. And, moreover, these laws and rules have a powerful effect in makiug individual and general Happiness coincident. That for the most part this coincidence holds in tolerably well-ordered communities seems evident. It is not to be denied, however, that buth for practical morality and for Utilitarian theory, the possible and occasionally actual, conflict between self and others is a great difficalty. But if we may believe in the "moral government of the world," the theoretical difficulty is overcome; and prominent opponents of Utilitarianism declare that the necessary postulate of Ethical Theory and Moral Conduct is the pre-supposition that "the agent who daly satisfies the community in which he shares by that same conduct satisfies hinself," or that self-realisation is only accomplished by self-sacrifice. On any theory the practical difficulty can only be minimised by the growth of individuals and communities in wisdom and benerolence; and on the Utilitarian view, every increase of Virtue in the agent means an increase of Happiness in others (at least), so that there cannot be an increase of Virtue in a community withont (ceteris paribus) a corresponding increase of Happiness.

Objection 10.-Though Happiness or Pleasure were the Eud, it would not follow that the attainment of the Greatest Amount of Pleasure possible woald be the nearest approximation to the End.*

Answer.-The difficulty or impossibility of attaining anp End in

* I have never understood the statement of the End as the greatest possible amount or sum of Pleusure or Huppiness, to mean more, or other, than as much as possible of concrete Happiness in concrete life. I do not know in what other sense those phrases could reasonably be understood. 
entire completeness or in full measure, does not seem to be a reasonable argument against the adoption of such an Endthe nearest approach to it that is possible for us, may be worth all our efforts. And if we are to reject any End that we cannot hope to attain completely, we should have to reject. perhaps, every End of human action that has been adopted by men. For instance, Perfection, Self-realisation, Virtue, Activity, can nerer be fully attained by any human being.

Objection 11.-A sum or series of Pleasures cannot be the End, because a sum or series cannot be enjoyed all at once.

Answer.-As time is a condition of human existence in this world, and as we live and act, think and will, enjoy and suffer, in snccessive and infinitely divisible moments of continuous time, this objection would seem to be applicable to any ultimate Good possible or conceivable for men. If every portion of time while present were delightinl, and when past or future were rememuered or anticipated with deligbt, what objection could be brought against such a Good of Consciousness on behalf of creatures living and thinking and feeling in time (though not in the present only)?

Objection 12.- "The pleasure of others cannot be a Good for $1 \mathrm{~s}$ if the good is pleasure."

Answer.-A precisely similar objection would seem to apply to any Good which is a Good of Consciousness, since each Man's consciousness is individual to himself. But tis take this particular statement of objection, it unay be pointed out that, if the good is pleasure qu$\hat{u}$ pleasure, all pleasure is goodtherefore the pleasure of others from an universal point of view, as well as the pleasure of myself from an individnal point of view-and though certainly an individual, I am not a mere individual. It is true that if I cannot desire anything but my own pleasure, then I cannot desire the pleasure of others; but if psychological Hedonism is denied (as it is denied by the latest and best exponents of Utilitarianism), then the pleasure of others may be an object of desire to me.* And bence, as an ethical eud, it is psycholoyically possible. The Hedonist does not put feeling into the place of reason-but he usks: Granteu that there is something which it is right and rational to seek, what is it? and failing all otber answers, be

* It cannot, I think, be denied that some people do desire the happiness of some uthers. Admilting this fuct, those who say that good is the object of desire must adnit that others' happiness may be a "Good" to me. 
tinds the reply: That which is ultimately and intrinsically good is happiness.

Objection 13.-A kind of converse of the objection that "the pleasure of others cannot be the good for us if the yood is pleasure," is the view (put forward, as I undurstand, by, e.g., Professor von Gizycki) that althongh the pleasure of others is Good to me, my own pleasure is not Good to me.

Answer.-This is, perhaps, the most curious of all Hedonistic views; for surely it is only if my own consciousness tells me that wy happiness is for me as an individuul intrinsically worth having, only on this condition is there ground for holding that the happiness of others is that which, for their sakes, it is worth while for me to promote. Why should I think that another's bappiness is any good to him, unless I feel that $m y$ happiness is a good to me? Can I judge his consciousness except by my own?

Again, each individuul when aiming at the happiness of others, since he does not aim at the happiness of one man alone, has to aim at both happiness and virtue (in so far as virtue conduces to happiness) in each. (And, of course, on the utilitarian view, conduciveness to happiness is the very content of virtue.) I think these considerations have some bearing on

(Objection 14.) Mr. Rashdall's objections to Utilitarianism, which are considered and answered by Professor Sidgwick in Mind, vol. xiv, p. 486.

Answer.-The supposed difficulty, that Utilitarianism assigns " a different end to the individual and to the race," might, it seems to me, be better expressed by sayiug, "a different end to the individual, qua individual merely, and to the individual quâa part of the whole," for there can be no end aimed at by men, und no end worthy of human attainment, except as aimed at and attained in the consciousness of individuals. The conflict (if confict there be) is a conflict within the conscionsness of individuals (as, indeed, Professor Sidgwick points out). It seems to me that Mr. Rashdall's objection of "a different end" would be more appropriate to the case of self versus one other solitary conscious individual.*

- The answers to Objections 9 and 12-14 are taken (cbiefly) from an article on "Rutional Hedonism," in the International Journal of Lithics, October, 1894. 
(3) As regards the compeling ends of action which have been suggested, they have to some extent already beeu incidentally considered. But a few words may be added regarding the end of Selfrealisation, and also regarding that ordinary "Common Sense" Morality which has been happily named "Dogmatic Intuitionism," and the still cruder form distinguished as Perceptional Intritionism.

To take Dogmatic Intuitionism first: it seens that reflection upon the generally received rules of such current morality must bring bome to us the fact that this body of Ethical precepts is wanting in the very first condition of scientific knowledge-that is to say, it is wanting in consistency. As Hume first poiuted out in detail, we find, however, that all these-sometimes clashing, sometimes obscure, sometimes incomplete-rules are, on examination, seen to be evidently in agreement in respect of their general felicific quality, and (as has been shown in the Methods of Ethics) we find it is possible to get both an explanation and a justification, on the one hand, of their partial validity, and, on the other hand, of their inadequacy, by reference to the "Happiness Principle"; and the recognition of this Principle in its connection with the common moral rules, furnishes that "Philosophic" form of Intuitionism which seems coincident with Utilitarianism or Universalistic Hedonism.

As regards what has been called Perceptional Intuitionism, it seems that no moralist of any repute adrocates it consistently; and, further, I should venture to question whether any person of ordinary reflection and intelligence would be found to seriousiy profess it. For by Perceptional Intuitionism is meant the view that the rightness or wrongness of every action is intuitively and immediately perceived without reference to rules or principles; and it is difficult to believe that any person in earnest about doing right can have failed to be sometimee in perplexity as to what is right in individual cases.

With regard to Self-realisation, it must be admitted that the meaning of that term (and therefore the worth of the End to which it refers) must depend entirely on the meaning given to Self. It is perhaps partly because in speaking of Self-realisation, the best or rational self is always tacitly implied, that the name has such a general attractireness, and appeals to men as an end which carries its own justification with it. But it must be remarked (1) that until further explained, Self-realisation is an End too vague to furnish any ethical guidance; and (2) that if the self intended is explained to mean the rational self, then, indeed, it is an End which all may accept, but it still remains vague until it has been pointed out what it is that is rational, what are the characteristics or content by which the rational self may be distinguished from those other elements of the whole self which are not rational. It is information on this 
point that is wanted-information as to the criterion by which the claim to rationality may in any case be tested. Reason, the Rational Self, must approve its claims to the appellation of Rational by rationality of choice; we require a test or criterion by reference to which the rationality or irratinnality of choice in any case may be determined. Reason cannot choose itself, and cannot exercise itself in emptiness, any more than the skill of a marksman or a musician can exercise or approve itself without the appropriate means and instruments. Its use and nature are to choose, amid ends and material which are something other tban Reason,--but of which some are more, and some less, worthy to be chosen.

Hence if Self-realisation (understood as the realisation of the Rational Self) is offered as an end that takes account of, and satisfies all parts of our nature, it appears that we have simply come back to the point from which we started-the preliminary admission or explanation that Good is what it is reasonable to seek and Right is what it is reasonable to do.

If the phrase "True Self" is regarded as synonymons with "Rational Self," or as preferable to it, it must be understood that True here means true to an ideal, not (in its more ordinary sense) true to fact.

When the True or Rational Self is explained to mean the Social Self, it seems very evident that Dualism of Practical Reason (which Universalistic Hedonism explicitly defines and accepts) is not necessarily eliminated by the adoption of Self-realisation as Ethical End.

\section{SYMPOSIUM-THE FREEDOM OF THE WLLL.}

\section{I.-By W. L. GiLdeA.}

HY "Will" I mean the rational appetite. There are three forms of :ppetite-tie natural, the sensitive, and the rational appetite. Natural appetite is the tendency of everything towards that which is suitable to its nature. "Everything already in possession of being," says St. Thomas (Quaest' Disput, de veritate, q. xxi, a. 2), "naturally likes that being and preserves it to the best of its power"; and, in the same article, he quotes Boethius as saying, "Providence has given to created things this chief principle of permanence, that, as far as they can, they bave a natural desire to persist in being." Natural appetite then, is found in man and in all things animate and inanimate. Von Hartmann digniñes this natural appetite by the name of will. He grants the word to the subject which has no claim 